\title{
Digestion of wheat gluten and potato protein by the preruminant calf: digestibility, amino acid composition and immunoreactive proteins in ileal digesta
}

\author{
P Branco-Pardal, JP Lallès, M Formal, P Guilloteau, R Toullec *
}

INRA, laboratoire du jeune ruminant, 65, rue de Saint-Brieuc, 35042 Rennes cedex, France

(Received 6 March 1995; accepted 27 September 1995)

\begin{abstract}
Summary - Three milk substitute diets, in which the protein was either provided exclusively by skim milk powder or partially $(52 \%)$ substituted by a native wheat gluten or a potato protein concentrate, were given to intact or ileo-cæcal cannulated preruminant calves. The apparent faecal nitrogen digestibility was lower $(P<0.05)$ with the potato than with the gluten and control diets $(0.90,0.93$ and 0.95 , respectively). The same trend was observed at the ileal level $(0.83,0.87$ and 0.91 , respectively). Apparent digestibilities of most amino acids were lower with the potato than with the control diet $(P<0.05$ for glutamic acid, proline, cystine, methionine, isoleucine, leucine, tyrosine and lysine). The same trend was observed with the gluten diet. Apparent digestibilities of glutamic acid and cystine were also lower $(P<0.05)$ with the potato than with the gluten diet. Protein fractions of $\mathrm{Mr} 43000$ and below 14000 were detected immunochemically in ileal digesta corresponding to the potato diet, but no immunoreactivity was found in digesta with the gluten diet. However, the considerable enrichment of digesta in glutamic acid and proline with gluten indicates that dietary protein fractions rich in these 2 amino acids escaped digestion in the small intestine. With the potato diet, the undigested fractions contained high levels of aspartic acid, glutamic acid and cystine.
\end{abstract}

digestion / preruminant calf / wheat gluten / potato protein / amino acid / immunoreactive protein

Résumé - Digestion du gluten de blé et des protéines de pommes de terre chez le veau préruminant : digestibilité, composition en acides aminés et en protéines immunoréactives des digesta iléaux. Trois laits de remplacement dans lesquels les protéines étaient apportées en totalité par de la poudre de lait écrémé ou partiellement (52\%) par du gluten de blé vital ou un concentrat protéique de pomme de terre ont été distribués à des veaux préruminants intacts ou munis d'une canule

* Correspondence and reprints 
réentrante iléo-cæcale. La digestibilité apparente de l'azote a été moins élevée $(\mathrm{p}<0,05)$ au niveau fécal avec le régime pomme de terre qu'avec les aliments gluten et témoin (respectivement 0,90, 0,93 et 0,95). Ilen a été de même à la fin de liléon (respectivement $0,83,0,87$ et 0,91 ). La digestibilité apparente de la plupart des acides aminés a été moins élevée avec l'aliment pomme de terre qu'avec l'aliment témoin ( $\mathrm{p}<0,05$ pour l'acide glutamique, la proline, la cystine, la méthionine, l'isoleucine, la leucine, la tyrosine et la lysine). Il en a été de même pour l'aliment gluten, mais seule la différence concernant la lysine a été significative. La digestibilité apparente de l'acide glutamique et celle de la cystine ont également été moins élevées ( $\mathrm{p}<0,05$ ) avec l'aliment pomme de terre qu'avec l'aliment gluten. Des fractions protéiques de $\mathrm{Mr} 43000$ et inférieur à 14000 ont été détectées immunochimiquement dans les digesta correspondant à l'aliment pomme de terre, mais aucune immunoréactivité n'a été observée dans ceux obtenus avec l'aliment gluten. Toutefois, l'enrichissement considérable des digesta en acide glutamique et en proline avec le gluten indique que des fractions alimentaires riches en ces 2 acides aminés ont échappé à la digestion dans l'intestin grêle. Dans le cas de l'aliment pomme de terre, les fractions indigérées ont été caractérisées par des teneurs élevées en acide aspartique, acide glutamique et cystine.

digestion / veau préruminant / gluten de blé / pomme de terre / acide aminé / protéine immunoréactive

\section{INTRODUCTION}

The replacement of milk protein with alternative sources in milk replacers is of great interest because of the high cost of the former. However, preruminant calves are very sensitive to protein quality. Inclusion of protein sources such as soya (Paruelle et al, 1972; Guilloteau et al, 1986; Khorasani et al, 1989), methanol-grown bacteria (Guilloteau et al, 1980; Sedgman et al, 1985), fish (Guilloteau et al, 1986) or whey (Toullec et al, 1969 ) in the milk replacer caused a decrease in nutrient digestibility, growth and feed efficiency. There has recently been increasing interest in the use of proteinaceous crops grown in Europe and industrial products. However, the utilization of some of these crops such as peas (Nunes do Prado et al, 1989; Bush et al, 1992a) or lupins (Tukur et al, 1995) may be limited by their relatively low protein content and perhaps reduced palatability or antigenic activity, which may decrease animal performance.

Wheat gluten is widely used for human consumption. It can be an alternative protein to skim milk for the preruminant calf. The flour may be extracted for the preparation of a product with a high protein content
$(82 \%)$, which has unusual viscoelastic properties. This characteristic may limit the gluten incorporation in diets to be given in liquid form. In addition, wheat gluten is devoid of antinutritional factors, such as lectins and oligosaccharides, but it does contain some protease inhibitors (Liener and Kakade, 1972). High digestibility values have been found at the faecal (Tolman and Demeersman, 1991) and ileal levels (Bush et al, $1992 b)$ for diets rich in solubilised wheat protein. However, little is known about the digestion of native wheat gluten (Toullec and Grongnet, 1990).

Potato protein, a by-product of the potatoprocessing industry, is another ingredient used in milk substitutes. Recovering potato proteins is of great interest not only to reduce their contribution to environmental pollution, but also because it is considered to be one of the more valuable plant proteins (Nuss and Hadziyev, 1980; Lindner et al, 1981). Industrial recovery of the protein from the effluents of potato starch mills is generally carried out by heat coagulation (Oosten, 1976; de Boer and Hiddink, 1977; Knorr et al, 1977). Although potato protein has an adequate amino acid (AA) composition and a low antitryptic activity, its use in milk replacers for calves would probably 
remain limited because of its poor suspendability, low supply and digestibility (Kolar and Wagner, 1991). However, the ileal digestibility of potato protein has not yet been evaluated.

The aim of this study was to determine the influence of native wheat gluten and potato proteins on ileal and faecal digestibilities of nutrients in preruminant calves.

\section{MATERIALS AND METHODS}

\section{Diets}

Two commercial protein concentrates containing 84 and $82 \%$ crude protein (CP; percentage of dry matter (DM)) prepared from wheat flour (Triticum aestivum) and potato juice (Solanum tuberosum L), respectively, were used (table I). The wheat concentrate was native gluten. The potato concentrate was obtained by heat coagu- lation of the juice. Both products were provided by Roquette Frères (Lestrem, France).

Three milk replacer diets (control, gluten and potato) containing approximately $23 \% \mathrm{CP}$ and $21 \%$ fat (DM basis) were prepared (table I). In the control diet, all the protein was provided by skim milk powder (SMP) (table II). In the other 2 diets, $51-52 \%$ of the protein was from either of the 2 concentrates; the remainder was provided by SMP and synthetic AA. L-Lysine-HCL and DL-methionine supplements were calculated in order to obtain total levels of 1.8 and $0.9 \%$ for lysine and sulphur-containing AA, respectively. The substitution rate was chosen in order to utilize the same SMP-based fat premix in the 3 diets. Actually, the gluten and potato diets were obtained at each meal by mixing the protein concentrates and complementary diets containing all the other ingredients. The AA composition of the protein concentrates and the whole diets is given in table III.

\section{Animals, feeding and digesta collection}

Six Holstein male calves (Experiment 1) were obtained at about $8 \mathrm{~d}$ of age, and fed a SMP-

Table I. Chemical composition of the protein sources and diets (\% of dry matter, ppm for trace minerals).

\begin{tabular}{|c|c|c|c|c|c|}
\hline & \multicolumn{2}{|c|}{ Proteins source a } & \multirow[b]{2}{*}{ Control a } & Diet a & \multirow[b]{2}{*}{ Potato b } \\
\hline & Gluten & Potato & & Gluten $\mathrm{b}$ & \\
\hline$N \times 6.25$ & 84.2 & 82.2 & 23.4 & 23.3 & 22.8 \\
\hline Fat & 4.7 & 4.7 & 21.1 & 21.6 & 21.3 \\
\hline $\mathrm{N}$-free extract & 10.3 & 9.9 & 48.9 & 48.1 & 49.1 \\
\hline Ash & 0.8 & 3.2 & 6.6 & 7.0 & 6.8 \\
\hline $\mathrm{Ca}$ & 0.12 & 0.22 & 1.06 & 1.11 & 1.05 \\
\hline$P$ & 0.24 & 0.61 & 0.87 & 0.81 & 0.86 \\
\hline $\mathrm{K}$ & 0.06 & 0.95 & 1.17 & 1.10 & 1.04 \\
\hline $\mathrm{Na}$ & 0.01 & 0.04 & 0.41 & 0.45 & 0.41 \\
\hline $\mathrm{Mg}$ & 0.03 & 0.05 & 0.10 & 0.16 & 0.12 \\
\hline $\mathrm{Cl}$ & 0.08 & 0.32 & 0.98 & 1.37 & 0.98 \\
\hline $\mathrm{Fe}$ & 66 & 151 & 4 & 15 & 28 \\
\hline $\mathrm{Zn}$ & 43 & 30 & 78 & 100 & 80 \\
\hline $\mathrm{Mn}$ & 18 & 6 & 53 & 57 & 56 \\
\hline $\mathrm{Cu}$ & 0 & 42 & 7 & 5 & 8 \\
\hline
\end{tabular}

a Analysed values; ${ }^{b}$ calculated from the values analysed in protein sources and complementary diets (see Materials and methods). 
Table II. Composition of the diets.

Ingredients (\% powder)
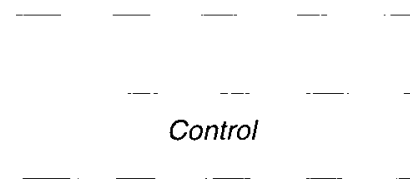

Diet

Fat premix a
Skim milk powder
Wheat gluten concentrate
Potato concentrate
Lactose
Pregelatinized starch
L-Lysine- $\mathrm{HCl}$
DL-Methionine
CaHPO
$\mathrm{NaCl}_{4} \cdot 2 \mathrm{H}_{2} \mathrm{O}$
$\mathrm{MgCl}_{2}$
$\mathrm{MgSO}_{4}$
$\mathrm{KCl}$
$\mathrm{Na}_{3} \mathrm{C}_{6} \mathrm{H}_{5} \mathrm{O}_{7} \cdot 2 \mathrm{H}_{2} \mathrm{O}$
$\mathrm{ZnSO}_{4} \cdot \mathrm{H}_{2} \mathrm{O}$
$\mathrm{MnSO}_{4} \cdot \mathrm{H}_{2} \mathrm{O}$
$\mathrm{CuSO}_{4} \cdot 5 \mathrm{H}_{2} \mathrm{O}$
$\mathrm{CMV} \mathrm{b}^{\circ}$

49.48

35.76

$-$

$-$

3.67

8

0.124

0.167

0.847

0.250

0.194

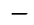

$-$

$-$

0.018

0.0025

0.77
Gluten

Potato

49.48

14.53

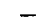

20.49

8

0.947

0.050

2.630

0.350

0.100

0.305

0.754

0.507

0.010

0.017

0.0023

0.77
49.48

-

14.73

21.44

8

0.118

0.080

2.691

0.350

0.066

0.360

1.000

0.529

0.010

0.018

0.0005

a Tallow (99.7\%) and emulsifier (0.3\%) homogenized into concentrated skim milk before spray-drying ( $400 \mathrm{~g} \mathrm{fat} / \mathrm{kg}$ dry matter). ${ }^{b}$ Contained (per $\mathrm{kg}$ diet): $5 \mathrm{~g}$ sorbitol, $200 \mu \mathrm{g} \mathrm{Kl}, 80 \mathrm{mg}$ bacitracine, $1.56 \mathrm{~g}$ choline chloride, $12000 \mathrm{IU}$ vitamin $A_{1} 3000 \mathrm{IU}$ vitamin $D_{3}, 50 \mathrm{mg}$ vitamin $E, 2.5 \mathrm{mg}$ vitamin $K_{3}, 7 \mathrm{mg}$ thiamine, $7 \mathrm{mg}$ riboflavine, $12 \mathrm{mg}$ niacine, $6 \mathrm{mg}$ pantothenic acid, $6 \mathrm{mg}$ pyridoxine, $600 \mu \mathrm{g}$ folic acid, $60 \mu \mathrm{g}$ vitamin $\mathrm{B}_{12}, 60 \mu \mathrm{g}$ biotin and $100 \mathrm{mg}$ vitamin $\mathrm{C}$.

based milk replacer. The calves started to consume the experimental diets at about 8 weeks of age. Each calf received each experimental diet for 2 weeks in different orders. The animals were fed twice daily (at 0830 and 1630) using open buckets. The amount of DM offered ( $58 \mathrm{~g} / \mathrm{kg}^{0.75 / \mathrm{d})}$ was adjusted weekly to the body weight of the animals. The switch between 2 test diets was accomplished over $2 \mathrm{~d}$ as described by Bush et al (1992b). Total faeces were collected during the last $5 \mathrm{~d}$ of each experimental period, and representative aliquots were frozen prior to subsequent freeze-drying and analysis.

Experiment 2 involved the same experimental design as Experiment 1 and used 5 Holstein heifer calves. At about 10 weeks of age, calves were fitted with an abomasal catheter and a reentrant ileo-caecal cannula (Guilloteau et al, 1986). Two weeks post-surgery, the calves started to receive the experimental diets by means of abomasal infusion twice daily. Abomasal infusion was used in order to get a perfect control of intake. The amount of DM offered was similar to that described in Experiment 1. Total digesta were collected from the ileum over the last $4 \mathrm{~d}$ of each experimental period (Guilloteau et al, 1986). Collection occurred under continuous stirring in flasks containing sodium benzoate ( $10 \mathrm{~g} / \mathrm{kg}$ digesta) to limit microbial activity. Digesta were weighed daily, and representative aliquots were frozen and freeze-dried before analysis.

\section{Chemical analyses}

The protein sources, control and complementary diets, faeces and ileal digesta were analysed for $D M$, nitrogen $(\mathrm{N})$, fat and ash according to previously described methods (Guilloteau et al, 1986). 
Table III. Amino acid (AA) composition of protein sources and diets ( $/ 100 \mathrm{~g} \mathrm{AA})$.

\begin{tabular}{|c|c|c|c|c|c|}
\hline & \multicolumn{2}{|c|}{ Protein source } & \multicolumn{3}{|c|}{ Diet } \\
\hline & Gluten a & Potato concentrate a & Controla & Gluten $\mathrm{b}$ & Potato b \\
\hline ASP & 3.17 & 12.35 & 7.76 & 5.26 & 10.10 \\
\hline THR & 2.74 & 6.32 & 4.44 & 3.55 & 5.50 \\
\hline SER & 4.63 & 5.35 & 5.29 & 4.88 & 5.36 \\
\hline GLU & 39.52 & 11.62 & 23.11 & 30.97 & 16.92 \\
\hline PRO & 12.73 & 5.04 & 9.26 & 11.07 & 7.12 \\
\hline GLY & 3.49 & 4.92 & 1.87 & 2.73 & 3.53 \\
\hline ALA & 2.56 & 4.89 & 3.13 & 2.87 & 4.10 \\
\hline CYS & 3.27 & 1.97 & 1.31 & 2.17 & 1.83 \\
\hline VAL & 4.05 & 6.95 & 6.13 & 5.03 & 6.71 \\
\hline MET & 1.75 & 2.37 & 3.46 & 2.16 & 2.70 \\
\hline ILE & 4.24 & 6.37 & 5.14 & 4.68 & 5.79 \\
\hline LEU & 7.29 & 10.48 & 10.01 & 8.42 & 9.99 \\
\hline TYR & 3.28 & 5.71 & 4.82 & 3.94 & 5.22 \\
\hline HIS & 1.95 & 2.34 & 2.71 & 2.30 & 2.51 \\
\hline LYS & 1.67 & 7.74 & 8.23 & 6.51 & 8.04 \\
\hline ARG & 3.65 & 5.58 & 3.32 & 3.47 & 4.57 \\
\hline$\sum A A(g / 16 g N)^{c}$ & 101.71 & 97.82 & 95.55 & 98.50 & 96.99 \\
\hline AAN $(\%$ total N) d & 77.38 & 83.09 & 76.36 & 77.68 & 80.29 \\
\hline
\end{tabular}

a Analysed values; ${ }^{b}$ calculated from the values analysed in protein sources and complementary diets; ${ }^{\circ} \sum$ AA: sum of $A A ; d$ Except amide- $N$ of asparagine and glutamine.

Mineral elements were analyzed in the protein sources, control and complementary diets by atomic absorption spectrometry, except phosphorus and chloride, which were determined by the phosphomolybdate method and potentiometry, respectively.

The protein sources, control and complementary diets, and ileal digesta were also analysed for AA by ion exchange chromatography after acid hydrolysis of samples in $6 \mathrm{~N} \mathrm{HCl}$ at $110^{\circ} \mathrm{C}$ for $24 \mathrm{~h}$, or $48 \mathrm{~h}$ in the case of valine and isoleucine. For the determination of sulphurcontaining AA, oxidation with performic acid was carried out prior to acid hydrolysis. Phenylalanine was not accurately determined in ileal digesta, probably because of their high mucoprotein content; therefore, the results for that AA were discarded. Tryptophan, which is destroyed by acid hydrolysis, was not analysed.

Proteins for immunoassays were extracted from the control diet and the corresponding digesta in phosphate-buffered saline (PBS) $\left(0.14 \mathrm{M} \mathrm{NaCl}, 0.02 \mathrm{M} \mathrm{Na}_{2} \mathrm{PO}_{4}, 0.0025 \mathrm{M} \mathrm{KCl}\right.$, $0.0015 \mathrm{M} \mathrm{KH}_{2} \mathrm{PO}_{4}, \mathrm{pH} 7.4$ ), from gluten and the corresponding digesta using an ethanol/water solution $(70: 30 \mathrm{vol} / \mathrm{vol})$, and from the potato concentrate and the corresponding digesta in borate buffer (0.1 $\mathrm{M} \mathrm{NaBO}_{3}, 0.15 \mathrm{M} \mathrm{NaCl}, \mathrm{pH} 8.0$ ). The extracts were prepared by continually stiring a fixed amount of sample $(1 \mathrm{~g} / 20 \mathrm{ml})$ for $60 \mathrm{~min}$ at room temperature $\left(25^{\circ} \mathrm{C}\right)$. They were then cleared by centrifugation at $12000 \mathrm{~g}$ for $30 \mathrm{~min}$. The soluble protein in the extracts was determined by the procedure of Lowry et al (1951).

Antibodies were raised in rabbits against 'native' proteins, ie extracted as described above from the gluten and potato concentrates. Each antigen was injected subcutaneously in 30 different sites in 3 rabbits. The amount of protein injected was approximately $1 \mathrm{mg}$ for each antigen emulsified (vol/vol) in complete (first injection) or incomplete Freund's adjuvant (Sigma, La Verpillière, France) (following injections). The 
immunization was repeated 4 times at $21 \mathrm{~d}$ intervals.

Immunoreactive proteins from the gluten and potato concentrates as well as from digesta were detected by a dot-blotting technique (Stott, 1989). Nitrocellulose (NC) sheets (Hybond-C super, Amersham, Buckinghamshire, UK) were cut to fit a 96-hole dot-blotting apparatus (Convertible Filtration Manifold System, Gibco BRL, Gaithersburg, MA, USA). After immersion in PBS, the membranes were placed in this system. Serial dilutions (1:1) of standardized protein solutions $(0.15 \mathrm{mg} / \mathrm{ml})$ were spotted $(5 \mu \mathrm{l})$ under vacuum on the NC disks in the wells. After $10 \mathrm{~min}$, the membranes were removed and immersed in a blocking solution (SMP, $50 \mathrm{mg} / \mathrm{ml}$ ) in Tris buffer (Tris $10 \mathrm{mM}, \mathrm{NaCl} 150 \mathrm{mM}, \mathrm{pH} 8.0$ ) and placed in shaking trays. After $30 \mathrm{~min}$, the membranes were rinsed 3 times with a Tris-Tween $20(0.5 \%$, $\mathrm{vol} / \mathrm{vol}$ ) buffer. Specific sera (dilution 1:500) were then incubated with the NC membranes. They were finally removed, washed in Tris-Tween 20 buffer, and incubated with antirabbit Igs conjugated with peroxidase (Sigma). After washing, the membranes were incubated with a solution of diaminobenzidine (Sigma) as the enzyme substrate, until an optimal brown staining developed (usually after $5 \mathrm{~min}$ ). The membranes were dried for $2 \mathrm{~h}$ at $37^{\circ} \mathrm{C}$ prior to visual analysis. Skim milk powder and digesta from the control calves were used as negative controls. Antigen levels were recorded as titres, eg, log2 dilutions, above which the brown colour disappeared. Protein concentrates and digesta samples were also analysed by immunoblotting after SDS-PAGE electrophoresis and electro-transfer on NC membranes (Gershoni and Palade, 1982; Stott, 1989).

\section{Statistical analyses}

The results were subjected to analysis of variance with repeated measures and the means were ranked according to Sheffé's test. Friedman's test was also used when variances were not homogeneous. Comparisons between the ileal and faecal digestibilities were carried out by the $U$-test. Significance was declared at $P \leq 0.05$.

Amino acid profiles of digesta protein were compared among themselves and with those of dietary, endogenous and bacterial proteins by the distance of $\chi^{2}$ (Guilloteau et al, 1983). The distance of $\chi^{2}$ between 2 proteins $i$ and $j$ is calculated as follows:

$$
\chi^{2}=16 \sum_{k=1}^{k=16}\left(\mathrm{AA}_{i k}-\mathrm{AA}_{j k}\right)^{2} /\left(\left(\mathrm{AA}_{i k}+\mathrm{AA}_{j k}\right) / 2\right)
$$

where $A A_{i k}$ and $A A_{j k}$ are the percentages of $A A_{k}$ in the sum of the assayed $A A$ in protein $i$ and $j ; k$ represents the different $A A$ and varies between 1 and 16. As the $\chi^{2}$ distance decreases, the similarity between the proteins increases. The proportions of dietary, endogenous and bacterial proteins which could be the main constituents of digesta protein were assessed by the method developed by Duvaux et al (1990). This method uses multiple regression analysis to establish the theoretical mixture of these proteins which minimizes the $\chi^{2}$ distance with regard to the AA profile of digesta. The compositions of the protein sources (table III), as well as literature data for gluten fractions and whole potato protein (listed below in table VI), were used for dietary protein. The mean composition of axenic lamb faeces (Combe, 1976) and calf meconium (Grongnet et al, 1981) was used as the model for undigested endogenous protein. The mean composition of pig (Mason et al, 1976) and sheep (Mason, 1979) faecal bacteria was used to represent the composition of ileal bacteria. The common protein escaping digestion in the small intestine of calves given diets based on milk, fish or soyabean protein (Guilloteau et al, 1986) was used as the model for the mixture of undigested endogenous and bacterial proteins (MEBP).

\section{RESULTS}

\section{Nutrient digestibility}

The apparent faecal nutrient digestibility was significantly lower $(P<0.05)$ with the gluten than with the control diet, except for $\mathrm{N}$ and nitrogen-free extract (NFE) (table IV). A similar trend was observed between the potato and the control diets, and the differences were significant for all nutrients except NFE. The digestibility of $\mathrm{N}$ was lower $(P<$ $0.05)$ with the potato than with the gluten diet. 
Table IV. Apparent ileal and faecal digestibilities of nutrients (means and SEM).

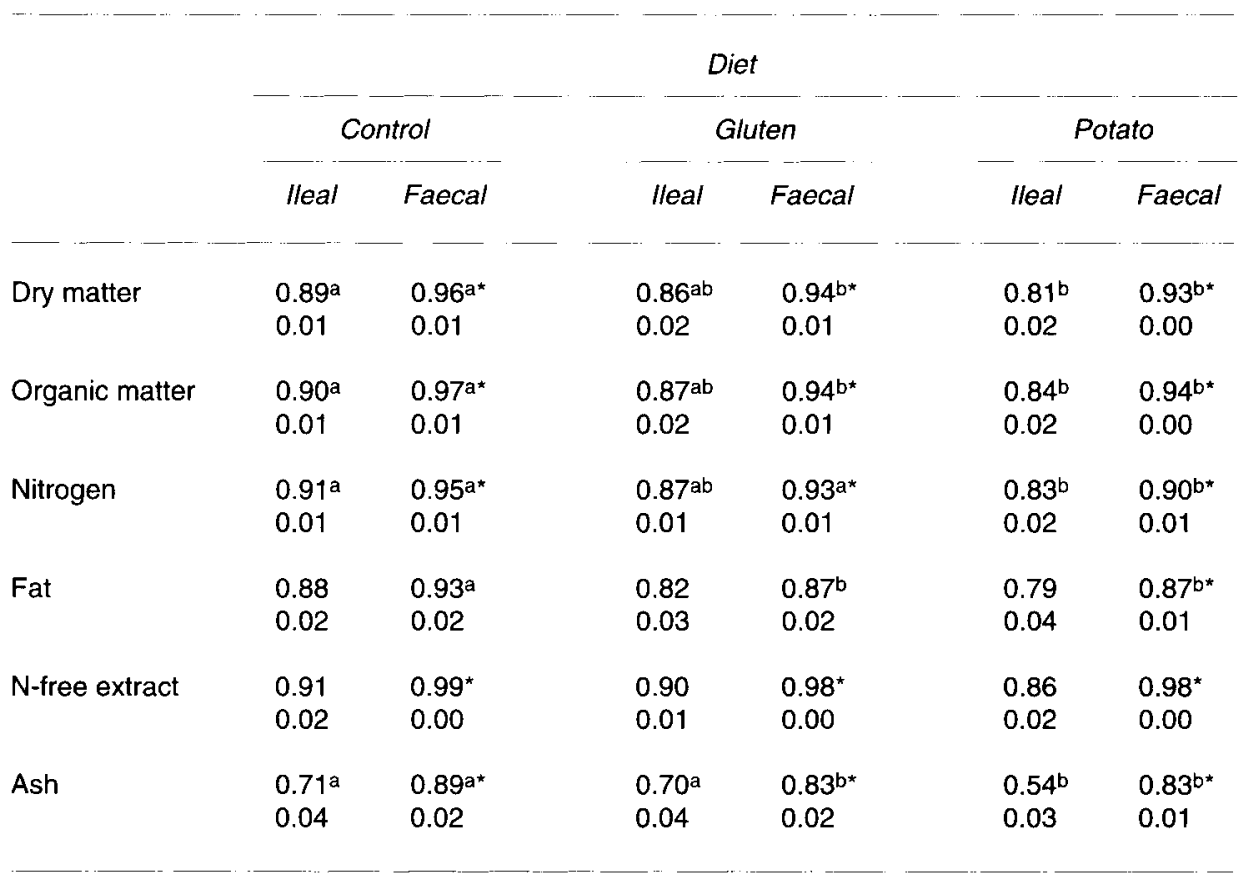

a,b,c At a given site (ileal or faecal) $P<0.05$ between values followed by different letters. $P<0.05$ between ileal and faecal values.

Both the gluten and potato diets resulted in lower ileal digestibility values than the control diet. However, the differences were only significant with the potato diet for DM, organic matter, $\mathrm{N}$ and minerals. Moreover, ileal digestibility values tended to be lower with the potato than the gluten diet, but the only significant difference was for minerals. Digestibility was significantly lower at the ileal than at the faecal level for the 3 diets, except for fat with the control and gluten diets.

The apparent ileal digestibilities of AA were lower with the gluten than the control diet, except for cystine, but the differences were only significant for lysine (table V). A similar trend was observed between the potato and the control diets (except for arginine) with significant differences for glutamic acid, proline, cystine, methionine, isoleucine, leucine, tyrosine and lysine. The potato, compared with the gluten diet, also resulted in a lower digestibility $(P<0.05)$ of glutamic acid and cystine. The digestibility of amino acid N (AAN) was also lower for the gluten and potato diets than for the control diet, but the differences were not significant $(P>$ 0.05). Digestibilities for all 3 diets, as compared to AAN, were higher for valine, methionine, isoleucine, leucine, tyrosine and arginine, and lower for aspartic acid, threonine, glycine, alanine and cystine.

\section{AA composition of protein sources and ileal digesta}

The gluten concentrate contained considerably more glutamic acid, proline, glycine, 
Table V. Apparent (means \pm SEM) and true (calculated) values for ileal digestibilities of AA.

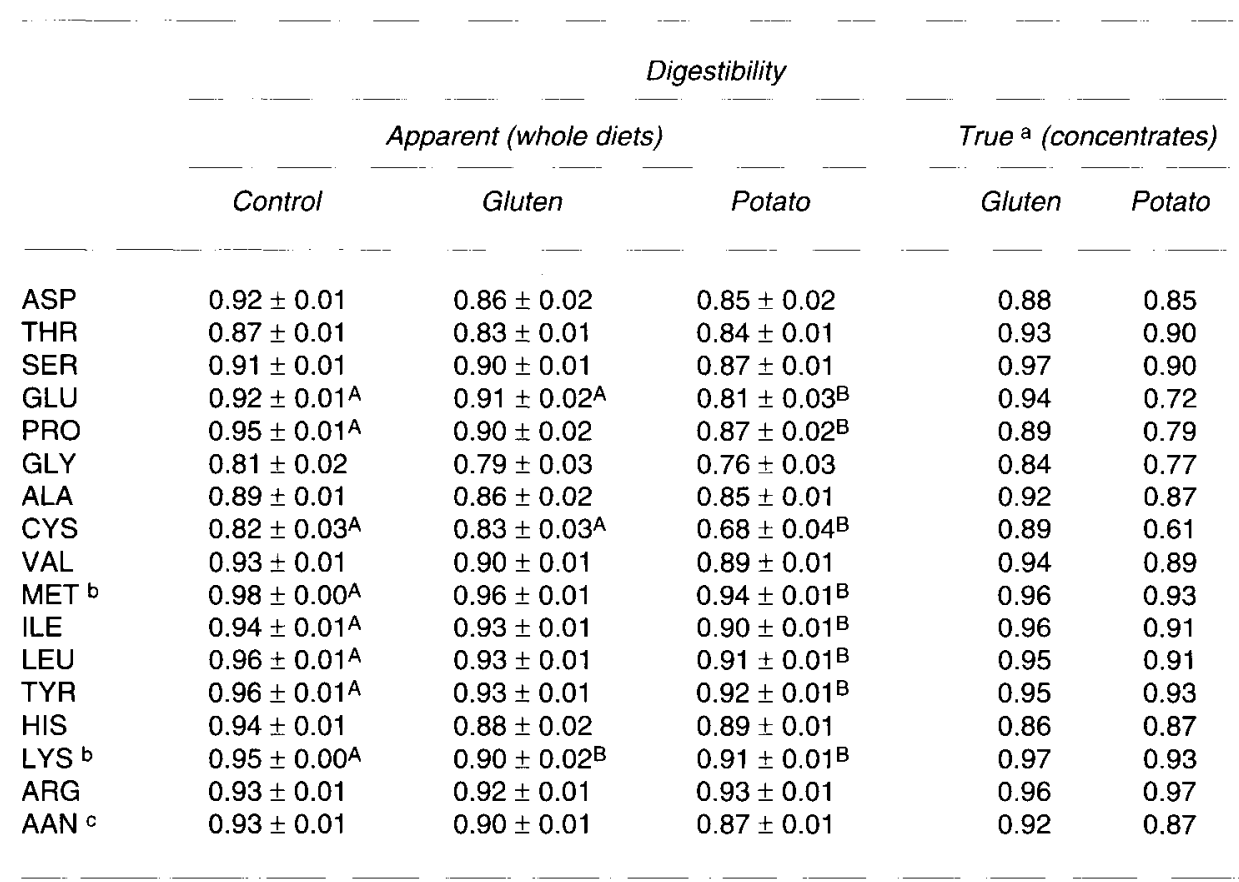

a Values calculated for the protein concentrates assuming that the digestion of milk protein was complete and that the amounts of AA per $\mathrm{kg} \mathrm{DM}$ intake escaping digestion in the small intestine with the control diet corresponded to the endogenous fraction with the other diets; $b$ supplement excluded; ${ }^{c}$ except amide- $\mathrm{N}$ of asparagine and aspartic acid. A,B $P<0.05$ between values followed by different letters.

cystine and less aspartic acid, leucine and lysine than SMP (table III). The potato concentrate contained more aspartic acid and glycine, and less glutamic acid and proline than SMP. Consequently, large distances of $\chi^{2}(\geq 88)$ were observed between diets.

The proportion of AAN ( $\%$ total $N$ ) was lower in ileal digesta than in the corresponding diets $(72,71$ and 65 vs 76,78 and 80 , with the control, gluten and potato diets, respectively). Digesta protein contained considerably more threonine, glycine, alanine, cystine (and glutamic acid with the potato diet), and less methionine, isoleucine, leucine, tyrosine and lysine (and proline and arginine with the control and potato diets, respectively) than the corresponding diets (fig 1 ; table III). This resulted in very large distance of $\chi^{2}$ between digesta and the corresponding diets $(\geq 161)$ (table VI).

Compared to control digesta, gluten digesta contained more proline and less alanine, valine and lysine $(P<0.05)$ (fig 1$)$. In potato digesta, the proportions of aspartic acid, glycine and cystine were higher $(P<$ 0.05 ) than in control digesta. Finally, the proportion of proline was higher and that of aspartic acid lower $(P<0.05)$ in gluten than in potato digesta. The global differences were larger between gluten digesta on the one hand and control or potato digesta on 


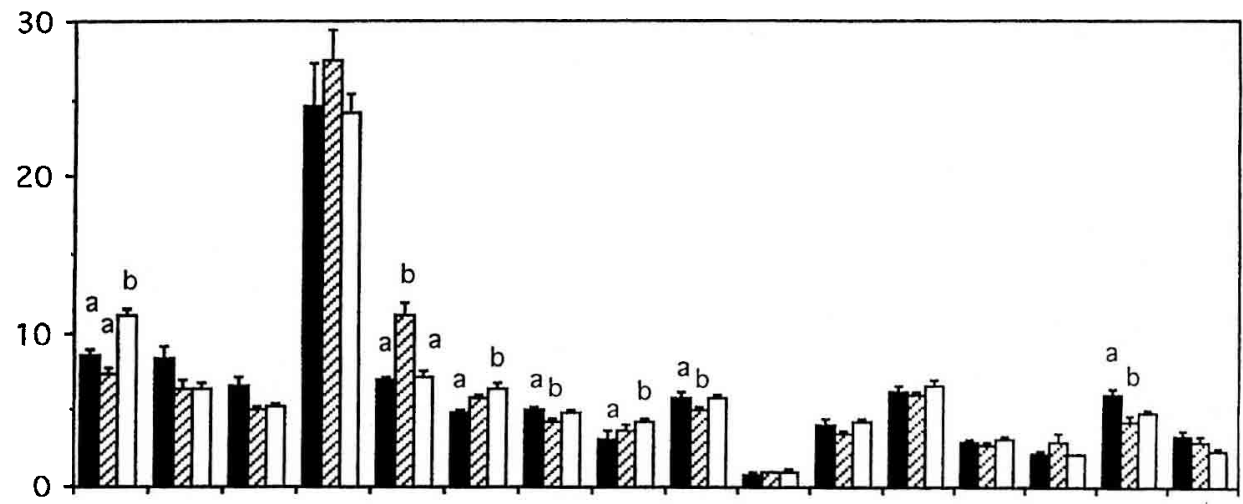

ASP THR SER GLU PRO GLY ALA CYS VAL MET ILE LEU TYR HIS LYS ARG

Fig 1. Amino acid composition ( $g / 100 \mathrm{~g}$ assayed $\mathrm{AA}$ ) of ileal digesta with the contol ( $\square$ ), wheat gluten ( $)$, and potato $(\square)$ diets. a,b $P<0.05$ between means with different letters. Vertical bars are standard errors.

the other $\left(\chi^{2}=83\right.$ or 81$)$ than between control and potato digesta $\left(\chi^{2}=45\right)($ table $\mathrm{VI})$. However, these values were small when compared to those recorded between digesta and the corresponding diets. Digesta were also more different from the protein sources $\left(\chi^{2} \geq 264\right)$. Gluten digesta differed largely from the major fractions or subunits of gluten $\left(\chi^{2} \geq 143\right)$. Purified glutenin was the protein the least different from gluten digesta, but the considerable $\chi^{2}$ distance (143) showed that this protein, as a whole, was poorly represented in digesta. The AA composition of digesta was also very different from that of endogenous and bacterial proteins $\left(\chi^{2} \geq 176\right)$.

The amounts of AA recovered at the end of the ileum relative to DM intake are presented in table VII. These amounts were always higher with the gluten and the potato diets than with the control diet. The differences between the potato and the control diets were significant for glutamic acid, proline, histidine and arginine. Differences between the 2 plant proteins were also significant for aspartic acid and lysine. The additional undigested protein fractions, com- pared with the control diet, were rich in glutamic acid and proline with the gluten diet, and in arginine and glutamic acid with the potato diet. These braces of AA represented 54.6 and $37.5 \%$ of the total, respectively. These fractions were very different from the endogenous, bacterial, gluten and potato proteins $\left(\chi^{2} \geq 223\right)$. These were closer to the corresponding whole digesta in the case of potato than for gluten $\left(\chi^{2}=55\right.$ and 377 , respectively).

\section{Immunoreactive proteins in ileal digesta}

Immunoreactive proteins, determined by immuno-blotting analysis, were detected in the extract of the gluten concentrate but not in the corresponding digesta. In contrast, immunoreactive proteins were detected in both the potato concentrate and digesta. These represented approximately $6 \%$ of the amount present in the potato protein extract (fig 2). However, the detected immunoreactive proteins belonged to the soluble protein fraction which represented only $2 \%$ of total potato protein. Finally, immuno-blot- 
Table VI. The $\chi^{2}$ distances between ileal digesta and theoretical protein mixtures.

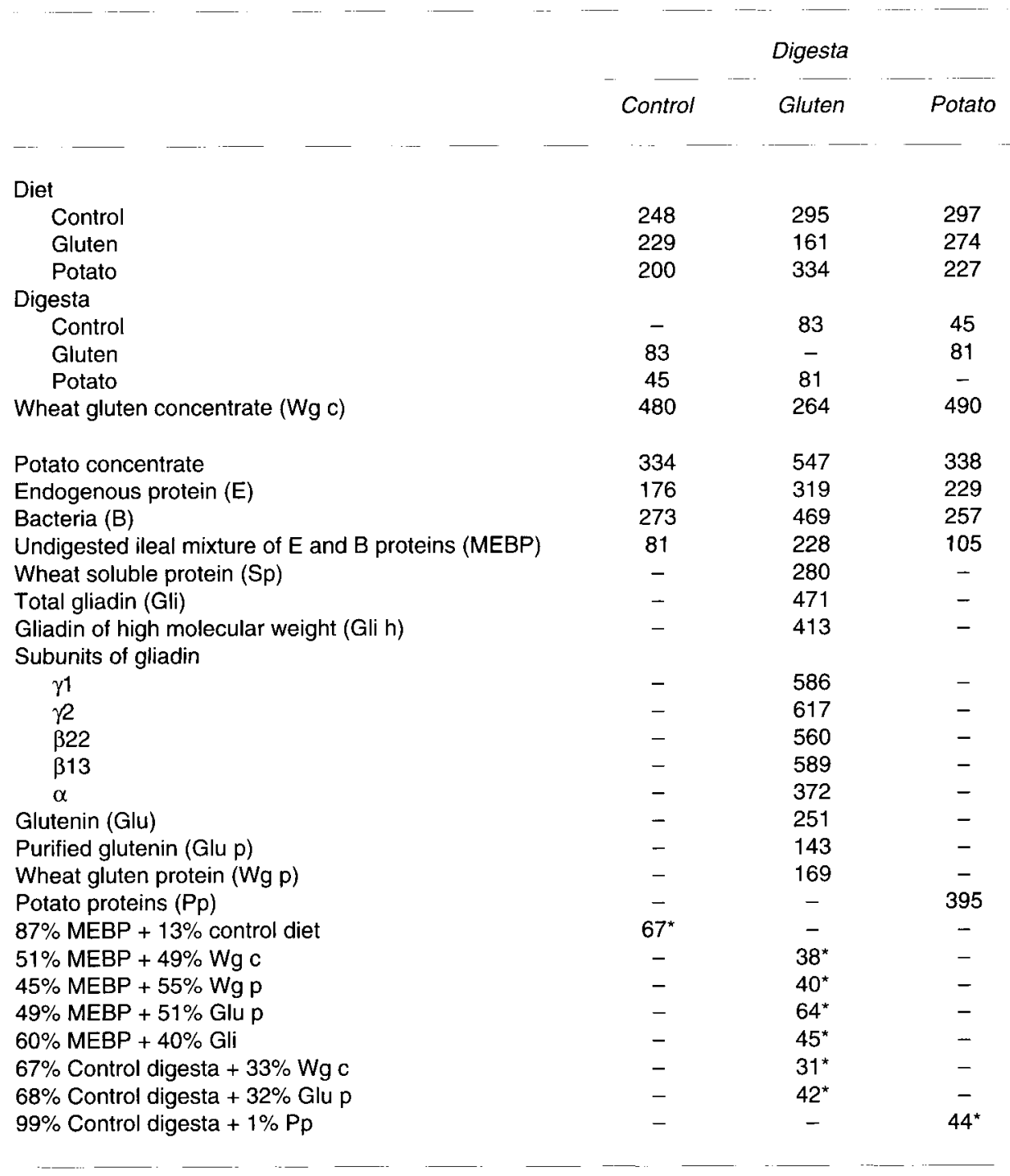

* $P<0.05$ for the fit between ileal digesta and retained theoretical protein mixtures. E: mean composition of axenic lamb faeces (Combe, 1976) and calf meconium (Grongnet et al, 1981). B: mean composition of pig (Mason et al, 1976) and sheep faecal bacteria (Mason, 1979). MEBP: common mixture of endogenous and bacterial proteins escaping digestion in calves given diets based on milk, fish or soyabean protein (Guilloteau et al, 1986). Sp (Feillet, 1976). Gli (Pépin, 1981). Gli h (Bietz and Wall, 1973). Subunits of gliadin (Ewart, 1976; Bietz et al, 1977; Terce-Laforgue et al, 1980). Glu according to Osborne fractionation (Orth and Bushuk, 1973). Glu p (Huebner and Wall, 1976). Wg p: theoretical mixture containing 0.20 soluble proteins, 0.35 gliadin and 0.45 glutenin (Popineau, 1985). Pp (reviewed by Davin, 1985). 
Table VII. Amount ( $\mathrm{mg} / \mathrm{kg}$ DM intake) of apparently undigested AA (means \pm SEM) and composition of the undigested protein ( $\%$ of assayed $A A)$.

Diet

Control Gluten Potato

Additional undigested a protein due to

Gluten Potato

$\begin{array}{lcccrr}\text { ASP } & 1410 \pm 151^{\mathrm{A}} & 1848 \pm 236^{\mathrm{A}} & 3582 \pm 478^{\mathrm{B}} & 5.01 & 13.88 \\ \text { THR } & 1345 \pm 101^{\mathrm{A}} & 1573 \pm 129 & 2076 \pm 189^{\mathrm{B}} & 2.61 & 4.68 \\ \text { SER } & 1050 \pm 76^{\mathrm{A}} & 1226 \pm 132 & 1648 \pm 154^{\mathrm{B}} & 2.00 & 3.82 \\ \text { GLU } & 4166 \pm 780 & 7201 \pm 1425 & 7863 \pm 110 & 34.69 & 23.63 \\ \text { PRO } & 1137 \pm 115 & 2876 \pm 555 & 2312 \pm 325 & 19.88 & 7.51 \\ \text { GLY } & 806 \pm 107^{\mathrm{A}} & 1473 \pm 224 & 2066 \pm 268^{\mathrm{B}} & 7.62 & 8.06 \\ \text { ALA } & 821 \pm 80^{\mathrm{A}} & 1053 \pm 116 & 1524 \pm 141^{\mathrm{B}} & 2.64 & 4.49 \\ \text { CYS } & 529 \pm 95^{\mathrm{A}} & 949 \pm 158 & 1401 \pm 162^{\mathrm{B}} & 4.81 & 5.57 \\ \text { VAL } & 966 \pm 119^{\mathrm{A}} & 1251 \pm 157 & 1838 \pm 163^{\mathrm{B}} & 3.25 & 5.57 \\ \text { MET } & 137 \pm 9^{\mathrm{A}} & 227 \pm 29 & 328 \pm 44^{\mathrm{B}} & 1.03 & 1.22 \\ \text { ILE } & 687 \pm 91^{\mathrm{A}} & 873 \pm 101 & 1371 \pm 114^{\mathrm{B}} & 2.13 & 4.37 \\ \text { LEU } & 1022 \pm 112^{\mathrm{A}} & 1494 \pm 190 & 2117 \pm 167^{\mathrm{B}} & 5.39 & 7.00 \\ \text { TYR } & 478 \pm 62^{\mathrm{A}} & 682 \pm 72 & 957 \pm 83^{\mathrm{B}} & 2.34 & 3.06 \\ \text { HIS } & 358 \pm 59 & 688 \pm 141 & 691 \pm 65 & 3.78 & 2.13 \\ \text { LYS } & 979 \pm 80^{\mathrm{A}} & 1047 \pm 95^{\mathrm{A}} & 1556 \pm 142^{\mathrm{B}} & 0.78 & 3.69 \\ \text { ARG } & 552 \pm 74 & 731 \pm 70 & 756 \pm 68 & 2.04 & 1.30\end{array}$

a Total amounts of AA recovered at the distal ileum with the gluten or potato diets minus those obtained with the control diet. a,b $P<0.05$ between values followed by different letters.

ting analysis showed that the immunoreactive proteins detected in the soluble fraction of the potato concentrate had relative molecular weights (Mr) of 43000,22000 , 20000 and 14000 , respectively after SDS denaturation. The immunoreactive proteins found in ileal digesta when the potato diet was used had Mr values of 43000 and below 14000 .

\section{DISCUSSION}

The digestibility of nutrients was lower with the gluten and potato diets compared to the control diet, both at the faecal and ileal levels (table IV). Nitrogen digestibility was also lower with the potato than with the gluten diet. The calculated value of the apparent faecal $\mathrm{N}$ digestibility for the gluten concen- trate was 0.91 , which is slightly below the value obtained by Toullec and Grongnet (1990) (0.94). This difference could be attributed to different inclusion levels (14.5 vs $5.5 \%$ ). In contrast, the calculated value of $\mathrm{N}$ digestibility for potato concentrate $(0.86)$ was slightly higher than previously recorded (0.83) with a similar product from this laboratory ( $R$ Toullec and JY Coroller, unpublished data).

The increased apparent digestibility of most nutrients between the ileal and the faecal levels is in line with earlier reports on milk replacers diets containing milk and nonmilk protein sources (Guilloteau et al, 1986; Nunes do Prado et al, 1989), except for fat, which was expected to show no apparent absorption in the hind gut. This situation could indicate that the fat digestion in fistulated calves was disturbed as compared to 


\begin{tabular}{|c|c|c|c|c|c|c|c|c|c|c|c|c|}
\hline & 1 & 2 & 3 & 4 & 5 & 6 & 7 & 8 & 9 & 10 & 11 & 12 \\
\hline A & $\mathrm{PC}^{*}$ & $\mathrm{Pc}^{*}$ & $\mathrm{PC}_{\mathrm{C}}$ & 0 & 0 & o & o & 0 & 0 & 0 & 0 & 0 \\
\hline B & SMP & SMP & 0 & 0 & 0 & 0 & 0 & 0 & 0 & 0 & 0 & 0 \\
\hline C & $\mathrm{Cd}$ & $\mathrm{D}^{*}$ & D & 0 & 0 & 0 & 0 & 0 & 0 & 0 & 0 & 0 \\
\hline D & $\mathrm{Cd}$ & $\mathrm{D}^{*}$ & 0 & 0 & 0 & 0 & 0 & 0 & 0 & 0 & 0 & 0 \\
\hline$E$ & $\mathrm{Cd}$ & $\mathrm{D}^{*}$ & D & 0 & 0 & 0 & 0 & 0 & 0 & 0 & 0 & 0 \\
\hline $\mathrm{F}$ & $\mathrm{Cd}$ & $\mathrm{D}^{*}$ & 0 & 0 & 0 & 0 & 0 & 0 & 0 & 0 & 0 & 0 \\
\hline G & $\mathrm{Cd}$ & $\mathrm{D}^{*}$ & D & 0 & 0 & 0 & 0 & 0 & 0 & 0 & 0 & 0 \\
\hline $\mathrm{H}$ & $\mathrm{Cd}$ & $\mathrm{D}^{*}$ & 0 & 0 & 0 & 0 & 0 & 0 & 0 & 0 & 0 & 0 \\
\hline
\end{tabular}

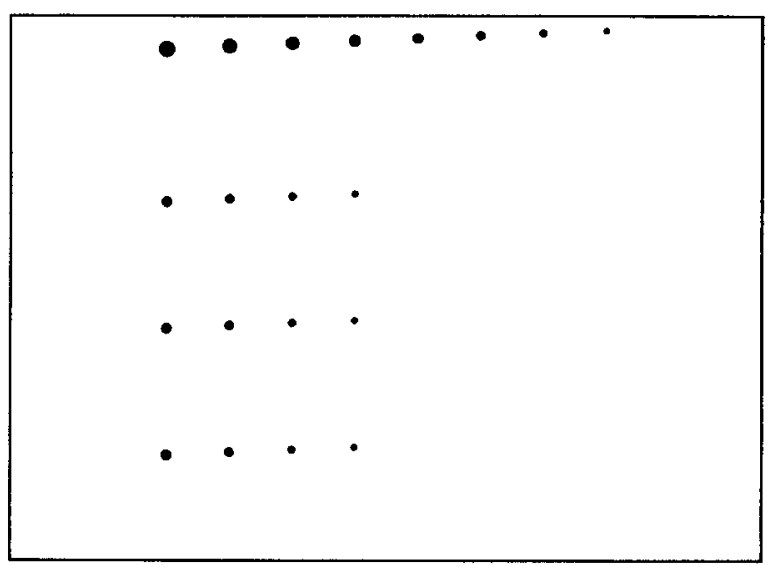

Fig 2. Schematic representation of dot-blotting analysis of potato concentrate and corresponding digesta. Top panel: location of samples (or treatments) and dilutions. Bottom panel: results. Pc: protein concentrate; SMP: skim milk powder; Cd: control digesta; D: digesta; O: serial dilution of protein solution from the left to the right; ${ }^{*}$ dots without antibodies. that in intact calves. However, as the changes were similar for the 3 diets this should not affect the other comparisons. The apparent ileal digestibilities of $\mathrm{N}$ for the gluten and potato concentrate were 0.84 and 0.76 , which represented 92 and $83 \%$, respectively, of that observed for SMP. The value for gluten is similar to previous data obtained with solubilised wheat protein ( $R$ Toullec and $P$ Guilloteau, unpublished results), whey, alcohol-treated soyabean and hydrolysed fish protein concentrates (Guilloteau et al, 1986; Caugant et al, 1993a, b). In contrast, the value for the potato concentrate was lower than values quoted previously and values obtained for a processed soyabean flour and pregelatinized peas (Nunes do Prado et al, 1989; Caugant et al, 1993a). Therefore, native gluten appears to be easily digested by preruminant calves, whereas additional processing could improve the digestibility of the potato protein concentrate.

The amounts of undigested $A A$ recovered at the distal ileum were always higher for the gluten and potato than for the control diet (table VII). Consequently, the true digestibility of AA for the gluten concentrate and especially for the potato concentrate was always lower than 1 (0.92 and 0.87 for NAA; table V). Essential and semiessential AA, except histidine and cystine, were more digestible than NAA for both concentrates. The relatively poor digestibility of cystine seems to be usual since this was previously observed with soya, peas and fish (Guilloteau et al, 1986; Nunes do Prado et al, 1989; Bush et al, 1992a). How- 
ever, solubilised wheat protein does not present this characteristic (R Toullec and $P$ Guilloteau, unpublished data). The results concerning the true digestibility of protein can be compared with those obtained in similar experiments in this laboratory with whey and alcohol-treated soya protein concentrates (Caugant et al, 1993a, b). Overall, the values obtained with the gluten concentrate were lower than those of whey for the essential AA, except for threonine, methionine, isoleucine and lysine. The highest differences were found for histidine and cystine $(-0.11$ and -0.06$)$. The gluten concentrate was digested to the same extent as the alcohol-treated soya concentrate, except for histidine $(-0.05)$; it even showed slightly higher values for threonine, cystine, valine and isoleucine $(+0.03$ to +0.05$)$. In contrast, the true digestibility of potato protein was clearly lower than that of whey concentrates, except for arginine. The difference was particularly noticeable for cystine $(-0.34)$. The potato concentrate was also less digestible than the soya concentrate, but differences were small except for cystine $(-0.24)$.

In milk-fed calves, the protein which escapes digestion in the small intestine appears to be almost entirely from endogenous and bacterial origin (Guilloteau et al, 1986). Replacing $52 \%$ of SMP by gluten or potato protein induced some changes in the AA composition of ileal digesta (fig 1). Differences between gluten and potato digesta were also noteworthy. The theoretical mixture between control digesta and gluten protein which minimized the $\chi^{2}$ distance $\left(\chi^{2}=\right.$ 31 ) with gluten digesta contained $33 \%$ of gluten concentrate $(P<0.05)$ (table $\mathrm{VI})$. This would suggest that the lower apparent $\mathrm{N}$ digestibility of the gluten diet might be due to incomplete digestion of gluten protein. The $\chi^{2}$ distance between the major proteins of gluten and their respective digesta suggested that glutenin could be the major undigested fraction. However, the AA composi- tion of the additional undigested protein obtained with the gluten diet, compared with the control diet, was very different from whole gluten, endogenous or bacterial protein $\left(\chi^{2}>495\right)$. This fraction was particularly rich in glutamic acid and proline as found in a previous experiment with hydrolysed gluten (Bush et al, 1992b). It could be mainly constituted by the repetitive pattern of Pro-Gin-GIn-Pro-Phe-Pro-GIn which is abundant in the $\mathrm{N}$-terminal domain of the major proteins of gluten (Tatham and Schrewry, 1985). When calculations were carried out, after excluding glutamic acid and proline, the $\chi^{2}$ distance between control and gluten digesta decreased $\left(\chi^{2}=41\right.$, instead of 83 ). Moreover, the $\chi^{2}$ distance between gluten digesta and MEBP was drastically reduced $\left(\chi^{2}=39\right.$, instead of 228$)$. This further supports the hypothesis that the background AA composition would be close between these digesta.

The theoretical mixtures between control digesta and dietary potato protein which minimized the $\chi^{2}$ distance with potato digesta contained only $1 \%$ potato protein. Therefore, the lower apparent $\mathrm{N}$ digestibility observed for the potato diet might be more due to increased losses of undigested endogenous and bacterial proteins than to the incomplete digestion of dietary protein. The AA composition of the additional undigested protein due to potato protein was very different from whole dietary protein $\left(\chi^{2}>223\right)$ but was closest to whole digesta $\left(\chi^{2}=55\right)$. In addition, no theoretical mixture of that protein with endogenous and bacterial proteins could be found to give a satisfactory fit with additional undigested fraction. Therefore, only small amounts of protein fractions having AA profiles similar to that of intact potato protein probably escaped digestion. These fractions were rich in aspartic acid, glutamic acid and cystine which appeared to be of relatively low apparent availability. 


\section{Immunoreactive proteins}

No immunoreactivity could be found in gluten digesta with the antibodies prepared against the native form of gluten protein. This probably means that the partially digested gluten fractions present in digesta had lost their reactive epitopes. Moreover, in ileal digesta from calves given a diet containing soyabean flour, evidence for the acidic polypeptides from soyabean glycinin could only be demonstrated indirectly through the use of anti-basic polypeptide antibodies, following SDS-PAGE electrophoresis under non-reducing conditions (HM Tukur and JP Lallès, unpublished data). The immunoreactive proteins detected in the soluble fraction from the potato concentrate had $\mathrm{Mr}$ values in agreement with the results of Ahldén and Trågårdh (1992) who described 3 major potato proteins ( 44 000,20000 and 14000 ), and with the observations of Suh et al (1990) about the molecular polymorphism of medium-Mr proteins (22 000, 23000 and 24000$)$. Specific proteins of $\mathrm{Mr} 43000$ and below 14000 were detected in ileal potato digesta. One could therefore hypothesize that some proteins with the highest $\mathrm{Mr}$ are found virtually intact at the end of the small intestine of the calf, as it has been shown for pea legumin (Bush et al, 1992a) and soyabean glycinin (HM Tukur and JP Lallès, unpublished data). The potato proteins with a low Mr in digesta might be digestion products, but a more precise characterisation is necessary. Although the immunoreactive protein detected here represented only a small fraction of the dietary protein, it could cause immunological reactions and impair calf performance, as shown with soya (Sissons, 1982) and peas (Bush et al, 1992a).

\section{CONCLUSION}

Replacing $52 \%$ of SMP protein by native gluten or potato protein resulted in a decrease in the apparent ileal and faecal digestibilities of nutrients. However, values obtained in the present experiment were similar to those of previous experiments with partially hydrolysed wheat or potato protein concentrates. The lower apparent digestibilities of gluten and potato protein might be due, at least partially, to a lower true digestibility. Epitopes of immunoreactive proteins from potato protein, but not from gluten, were probably sufficiently intact at the end of the small intestine to be recognized by specific antibodies raised against the native structures. The true digestibility of potato protein was lower than that of gluten protein, especially for cystine. Finally, the utilization of more specific methods, such as the ${ }^{15} \mathrm{~N}$ technique (Souffrant, 1991), are required to get a more quantitative estimation of endogenous protein losses and residual dietary protein in ileal digesta.

\section{ACKNOWLEDGMENTS}

The authors wish to thank all the staff of the experimental facilities for their care of the animals, J Quillet for gathering the literature, and Roquette Frères, 62136 Lestrem, France for financial support.

\section{REFERENCES}

Ahldén I, Trågårdh G (1992) A study of soluble proteins from potato varieties used in the Swedish starch industry. Food Chem 44, 113-118

Bietz JA, Wall JS (1973) Isolation and characterization of gliadin like subunits from glutenin. Cereal Chem 50, 537-547

Bietz JA, Huebner FR, Sanderson JE, Wall JS (1977) Wheat gliadin homology revealed through $\mathrm{N}$-terminal amino acid sequence analysis. Cereal Chem 54, 1070-1083

Bush RS, Toullec R, Caugant I, Guilloteau P (1992a) Effects of raw pea flour on nutrient digestibility and immune responses in the preruminant calf. J Dairy Sci 75, 3539-3552

Bush RS, Toullec R, Guilloteau P, Barré P (1992b) Digestibilité iléale d'un gluten de blé partiellement 
hydrolysé chez le veau préruminant. Ann Zootech $41,31-32$

Caugant I, Toullec R, Formal M, Guilloteau P, Savoie $L$ (1993a) Digestibility and amino acid composition of digesta at the end of the ileum in preruminant calves fed soyabean protein. Reprod Nutr Dev 33, 335-347

Caugant I, Toullec R, Guilloteau P, Savoie L (1993b) Whey protein digestion in the distal ileum of the preruminant calf. Anim Feed Sci Technol 41, 223-236

Combe $E$ (1976) Influence de la microflore sur la composition en acides aminés des fèces des agneaux. C R Soc Biol 170, 787-793

Davin A (1985) Propriétés biochimiques et physicochimiques des protéines d'organes végétaux de réserve enterrés (tubercules et racines). In: Protéines végétales (BP Godon, ed), Tec \& Doc, Lavoisier, Paris, 245-261

De Boer R, Hiddink J (1977) Reverse osmosis and ultrafiltration in the treatment of food waste. Chemical Engineering in a Hostile World, EUROCHEM Conference, Paper No 38, Session 8, $16 \mathrm{p}$

Duvaux C, Guilloteau P, Toullec R, Sissons JW (1990) A new method of estimating the proportions of different proteins in a mixture using amino acid profiles: application to undigested proteins in the preruminant calf. Ann Zootech 39, 9-18

Ewart JAD (1976) A Cappelle-Desprez $\beta$-gliadin of high mobility. J Sci Food Agric 27, 695-698

Feillet $\mathrm{P}(1976)$ Les albumines et globulines du blé. Ann Technol Agric 25, 203-216

Gershoni JM, Palade GE (1982) Electrophoretic transfer of proteins from sodium dodecyl sulphate polyacrylamide gels to a positively charged membrane filter. Anal Biochem 124, 396

Grongnet JF, Patureau-Mirand P, Toullec R, Prugnaud $J$ (1981) Utilisation des protéines du lait et du lactosérum par le jeune veau préruminant. Influence de l'âge et de la dénaturation des protéines du lactosérum. Ann Zootech 30, 443-464

Guilloteau P, Patureau-Mirand P, Toullec R, Prugnaud $J(1980)$ Digestion of milk protein and methanolgrown bacteria protein in the preruminant calf. II. Amino acid composition of ileal digesta and faeces and blood levels of free amino acid kinetics. Reprod Nutr Dev 20, 615-629

Guilloteau P, Sauvant D, Patureau-Mirand P (1983) Methods of comparing amino acid composition of proteins: application to undigested proteins in the preruminant calf. Ann Nutr Metab 27, 457-469

Guilloteau P, Toullec R, Grongnet JF, Patureau-Mirand $P$, Prugnaud J (1986) Digestion of milk, fish and soyabean protein in the preruminant calf: flow of digesta, apparent digestibility at the end of the ileum and amino acid composition of ileal digesta. $\mathrm{Br} J$ Nutr 55, 571-592

Huebner FR, Wall JS (1976) Fractionation and quantitative differences of glutenin from wheat varieties varying in backing quality. Cereal Chem 53,258 269

Huebner FR, Wall JS (1980) Wheat glutenin: effect of dissociating agents on molecular weight and composition as determined by gel filtration chromatography. $J$ Agric Food Chem 28, 433-438

Khorasani GR, Sauer WC, Maenhout F, Kennelly JJ (1989) Substitution of milk protein with soy flour or meat-solubles in calf milk replacers. Can J Anim Sci 69, 373-382

Knorr D, Kohler GO, Betschart AA (1977) Potato protein concentrates: the influence of various methods of recovery upon yield, compositional and functional characteristics. $J$ Food Process Preserv 1 , 235-247

Kolar CW, Wagner TJ (1991) Alternative protein use in calf milk replacers. In: New Trends in Veal Calf Production (JHM Metz, CM Groenestein, eds), Pudoc Press, Wageningen, 211-215

Laemmli UK (1970) Cleavage of structural protein during the assembly of the head of bacteriophage $T 4$. Nature (Lond) 227, 680-685

Liener IE, Kakade ML (1972) Protease inhibitors: In: Toxic Constituents of Plant Foodstuffs (IE Liener, ed), Academic Press Inc, New York, 7-68

Lindner P, Kaplan B, Weiler E, Ben-Gera I (1981) Fractionation of potato juice proteins into acid-soluble and acid-coagulable fractions. Food Chem 6, 323335

Lowry OH, Rosebrough NJ, Farr AL, Randall RJ (1951) Protein measurement with the Folin phenol reagent. $J$ Biol Chem 193, 265-275

Mason VC (1979) The quantitative importance of bacterial residues in the non-dietary faecal nitrogen of sheep. I. Methodology studies. Z Tierphysiol Tierernähr u Futtermittelkd 41, 131-139

Mason VC, Just A, Bech-Anderens S (1976) Bacterial activity in the hind gut of pigs. 2 . Its influence on the apparent digestibility of nitrogen and amino acids. $Z$ Tierphysiol Tierernähr u Futtermittelkd 36, 310324

Nunes do Prado I, Toullec R, Guilloteau P, Guéguen J (1989) Digestion des protéines de pois et de soja chez le veau préruminant. II. Digestibilité apparente à la fin de l'iléon et du tube digestif. Feprod Nutr Dev 29, 425-439

Nuss J, Hadziyev D (1980) Effect of heat on molecular weight and charge of potato proteins. Can Inst Food Sci Technol J 13,80-6

Oosten (1976) Protein from potato starch mill effluent. In: Food from Waste (GG Birch, KJ Parker, JT Worgan, eds), Applied Science, London, 196-204

Orth RA, Bushuk W (1973) Studies of glutenin. I. Comparison of preparative methods. Cereal Chem 50 , 106-114 
Paruelle JL, Toullec R, Frantzen JF, Mathieu CM (1972) Utilisation des protéines par le veau préruminant à I'engrais. I. Utilisation digestive des protéines de soja et des levures d'alcanes incorporées dans les aliments d'allaitement. Ann Zootech 21, 319-331

Pépin D (1981) Étude des propriétés tensioactives des fractions de gliadines de blé extraites par des traitements physiques. Thèse de $3^{e}$ cycle, université ParisSud, Orsay

Popineau $Y$ (1985) Propriétés biochimiques et physicochimiques des protéines de céréales. In: Protéines végétales (BP Godon, ed), Tech \& Doc, Lavoisier, Paris, 161-210

Sedgman CA, Roy JHB, Thomas J, Stobo IJF, Ganderton $P$ (1985) Digestion, absorption and utilisation of single-cell protein by the preruminant calf. The true digestibility of milk and bacterial protein and the apparent digestibility and utilisation of their constituent amino acids. Br J Nutr 54, 219-224

Sissons JW (1982) Effects of soyabean products on digestive processes in the gastrointestinal tract of preruminant calves. Proc Nutr Soc 41, 53-61

Souffrant WB (1991) Endogenous nitrogen losses during digestion in pigs. In: Digestive Physiology in Pigs (MWA Verstegen, J Huisman, LA Den Hartog, eds), Pudoc Press, Wageningen, 147-166

Stott DI (1989) Immunoblotting and blotting. J Immunol Methods 119, 153-187
Suh SG, Peterson JE, Stiekema WJ, Hannapel DJ (1990) Purification and characterization of the 22kilodalton potato tuber proteins. Plant Physiol 94, 40-45

Tatham AS, Schrewry PR (1985) The conformation of wheat gluten proteins. The secondary structures and thermal stabilities of $\alpha, \beta, \gamma$ and $\omega$ gliadins. $J$ Cereal Sci 3, 103-113

Terce-Laforgue T, Charbonnier L, Moss J (1980) Isolation and characterization of $\beta$-gliadin fractions. Biochim Biophys Acta 625, 118-126

Tolman GH, Demeersman M (1991) Digestibility and growth performance of wheat soluble protein for veal calves. In: New Trends in Veal Calf Production (JHM Metz, Groenestein, eds), Pudoc Press, Wageningen, 227-233

Toullec R, Grongnet JF (1990) Remplacement partiel des protéines du lait par celles du blé ou du maïs dans les aliments d'allaitement ; influence sur l'utilisation digestive chez le veau de boucherie. INRA Prod Anim 3, 201-206

Toullec R, Mathieu CM, Vassal L, Pion R (1969) Utilisation digestive des protéines du lactosérum par le veau préruminant à l'engrais. Ann Biol Anim Bioch Biophys 9, 661-664

Tukur H, Branco Pardal P, Formal M, Toullec R, Lallès JP, Guilloteau $P$ (1995) Digestibility, blood levels of nutrients and skin responses of calves fed soyabean and lupin proteins. Reprod Nutr Dev 35 , $27-44$ 